\title{
China-GOES (Article 21.5): Time to Clarify the Standard for Price Suppression and Price Depression in AD/CVD Investigations
}

\author{
JULIA QIN* \\ Wayne State University, USA and Tsinghua University, China \\ HYLKE VANDENBUSSCHE* * \\ University of Leuven, Belgium
}

\begin{abstract}
This dispute concerns the measures China took to implement the Dispute Settlement Body's rulings in China-GOES, which had found a number of violations with respect to China's antidumping and countervailing duties imposed on grain oriented flat-rolled electrical steel (GOES) imported from the United States. In this compliance proceeding, the United States claimed that the Redetermination issued by China's Ministry of Commerce (MOFCOM) continued to violate WTO law. At the center of the dispute were MOFCOM's findings that the US imports had the effect of suppressing and/or depressing the prices of domestic like products. While the Panel reached the conclusion that the MOFCOM findings were inconsistent with WTO rules, it did not clarify the criteria for determining such price effects. In this comment, we call for the adoption of a clearer and more objective standard for determining price suppression and price depression in antidumping and countervailing duty investigations, via the tools of economic modeling.
\end{abstract}

\section{Introduction}

On 16 November 2012, the WTO Dispute Settlement Body (DSB) adopted the Panel and Appellate Body Reports in China-Grain Oriented Flat-Rolled Electrical Steel from the United States (China-GOES). ${ }^{1}$ These Reports found that China's levy of antidumping and countervailing duties (AD/CVD) on US steel imports, as set forth in the Ministry of Commerce (MOFCOM) Notice No. 21 [2010], was inconsistent with the Antidumping Agreement (ADA) and the Agreement on Subsidies and Countervailing Measures (SCM Agreement). ${ }^{2}$ To

\footnotetext{
* Email: ya.qin@wayne.edu.

**Email: Hylke.Vandenbussche@kuleuven.be.

1 China-Grain Oriented Flat-Rolled Electrical Steel from the United States, Panel Report, WT/DS414/ R (15 June 2012), modified by Appellate Body report, WT/DS414/AB/R (18 October 2012) [hereinafter China-GOES].

2 For comments on these reports, see Prusa and Vermulst (2014).
} 
implement the DSB recommendations and rulings, MOFCOM issued a Redetermination on 31 July 2013, pursuant to which China continued to impose $\mathrm{AD} / \mathrm{CVD}$ on the US steel imports, albeit with some adjustments on the rates of the duties. ${ }^{3}$

In February 2014, the United States brought this case under Article 21.5 of the Dispute Settlement Understanding (DSU), claiming that MOFCOM's Redetermination failed to comply with the requirements of the ADA and the SCM Agreement. Notably, this is the first compliance dispute brought against China under DSU Article 21.5.

The Panel in the compliance proceeding issued its report on 31 July $2015,{ }^{4}$ which supported some of the US claims. Specifically, the Panel found that MOFCOM's Redetermination was inconsistent with certain ADA and SCM provisions regarding injury determination and disclosure of essential facts. China did not appeal the Panel decision, as its AD/CVD measures had expired during the Panel proceeding in April 2015.5 The DSB adopted the Panel Report on 31 August 2015.

In this compliance case, it was not disputed that the US steel imports at issue were both dumped and subsidized; the dispute, instead, centred on whether the dumped and subsidized imports caused material injury to China's domestic industry. Specifically, the key issue in the injury determination was whether the US imports had the effect of suppressing and/or depressing prices of China's domestic like products, as found by the MOFCOM in its Redetermination. The disclosure issues raised in this case all concerned the adequacy of MOFCOM's disclosure of essential facts regarding its injury determination via these price effects.

To understand the key issue in this case, it is necessary to first understand the concepts of price suppression and price depression. Under the ADA and SCM Agreement, the national authority in AD/CVD investigations is required to consider, in its injury determination, three types of effects of subject imports on the prices of domestic like products: price undercutting, price depression, and price suppression. As is commonly understood:

(a) 'Price undercutting' indicates a situation in which subject imports are priced below domestic like products.

(b) 'Price depression' depicts a situation in which the prices of domestic like products have declined, due to the presence of subject imports.

(c) 'Price suppression' suggests a situation in which the prices of domestic like products have not increased as it should, due to the presence of subject imports.

3 Available in Chinese at: www.mofcom.gov.cn/article/b/g/201310/20131000340655.shtml.

4 Panel Report, China-Grain Oriented Flat-Rolled Electrical Steel from the United States, Recourse to Article 21.5 of the DSU by the United States, WT/DS414/RW (31 July 2015) [hereinafter China-GOES 21.5].

5 Panel Report, China-GOES 21.5, paras. 6.21-6.25 (ruling that China's submission of MOFCOM's public notice of termination of the measures was untimely). 
Note that price depression and price suppression may occur regardless of the price level of subject imports as compared to that of domestic like products.

In practice, it is relatively easy to establish 'price undercutting', as it is based on a showing of the fact that the prices of subject imports lies below those of domestic like products. In comparison, it is much harder to establish 'price depression' and 'price suppression', because these concepts involve a counterfactual situation: were it not for the subject imports, the prices of domestic like products would not have declined (price depression) or would have increased more (price suppression).

It is important to note that, while MOFCOM's Redetermination found price suppression and price depression, it did not make a finding on price undercutting. The evidence in this case suggests that the US imports were priced higher than domestic like products during the period of investigation.

Somewhat surprisingly, China-GOES appears to be the first WTO case to address the issues concerning price suppression/depression in the context of $\mathrm{AD} / \mathrm{CVD}$ investigations. In the original proceedings, the Appellate Body discussed the concepts of price suppression and price depression, but did not focus on the issue of what is required to establish such price effects. In the compliance proceeding, the Panel concluded that MOFCOM's findings on price suppression/depression did not meet the requirements of the ADA and SCM Agreement, but it also did not specify how such price effects should be established under the ADA and SCM Agreement. As a result, it remains unclear as to what constitutes a proper analysis of price suppression and price depression in the AD/CVD context. The lack of a standard on the determination of these price effects is undesirable as a matter of WTO law and policy.

In this comment, we call for the adoption of a clear and objective standard for determining price suppression/depression in AD/CVD investigations. Specifically, we advocate the need for economic modeling in making the determination. In the rest of the comment, we will explain our proposal from the legal perspective (Section 2), the economic perspective (Section 3) and the policy perspective (Section 4).

\section{Legal analysis: what is required to establish price suppression/depression?}

\subsection{The textual basis}

The investigating authorities in antidumping and countervailing proceedings are required to examine the price effects of dumped or subsidized imports on domestic like products. The general obligation to examine such price effects is set out in ADA Article 3.1 and SCM Article 15.1, which contain identical provisions except for the reference to 'dumped' (in ADA) or 'subsidized' (in SCM) imports:

A determination of injury for purposes of Article VI of GATT 1994 shall be based on positive evidence and involve an objective examination of both (a) the volume of the [dumped or subsidized] imports and the effect of [dumped or subsidized] 
imports on prices in the domestic market for like products, and (b) the consequent impact of these imports on domestic producers of such products.

The requirement to examine 'price effect' is then elaborated in ADA Article 3.2 and SCM Article 15.2:

With respect to the effect of [dumped or subsidized] imports on prices, the investigating authorities shall consider whether there has been a significant price undercutting by the [dumped or subsidized] imports as compared with the price of a like product of the importing Member, or whether the effect of such imports is otherwise to depress prices to a significant degree or prevent price increases, which otherwise would have occurred, to a significance degree.

Thus, in accordance with ADA Article 3.2 and SCM Article 15.2, the investigating authorities need to consider three types of price effect of dumped or subsidized imports on domestic like products: (i) whether there has been 'a significant price undercutting' by such imports, (ii) whether the effect of such imports is otherwise to depress prices to a significant degree (i.e., significant price depression), or (iii) whether the effect of such imports is to 'prevent price increases, which otherwise would have occurred', to a significant degree (i.e., significant price suppression).

\subsection{WTO case law}

Articles 3.2 and 15.2 do not define the terms of 'price undercutting', 'price depression', or 'price suppression', or prescribe any particular methodology in determining these price effects. Nonetheless, WTO case law has established certain criteria for identifying the effect of price undercutting. According to the Appellate Body, price undercutting 'involves situations where imports are being sold at prices lower than the domestic like products', and the finding of price undercutting requires 'a dynamic assessment of price trends' over the period of investigation. ${ }^{6}$

By comparison, the criteria for establishing price depression and price suppression are less clear. In China-GOES, the Appellate Body explained that the concept of price depression 'refers to a situation in which prices are pushed down, or reduced, by something'. 7 The finding of price depression, therefore, involves an observation of 'a price decline', and an analysis of whether the price decline 'stems from' dumped or subsidized imports. ${ }^{8}$ As for price suppression, the Appellate Body has established the following: (i) price suppression may occur with or without price undercutting or price depression; (ii) price suppression cannot be properly examined without a consideration of whether, in the absence of subject imports, prices 'otherwise would have' increased; (iii) the effect of

6 Appellate Body Reports, China - Measures Imposing Anti-dumping Duties on High Performance Stainless Steel Seamless Tubes (HP-SSST) from Japan and the European Union, WT/DS454, 460/AB/R, adopted 28 October 2015, para. 5.160.

7 Appellate Body Report, China-GOES, para. 141.

8 Ibid., paras. $138,141$. 
price suppression stems from relevant aspects of dumped or subsidized imports, 'including the price and/or the volume of such imports'. 9 Yet, the Appellate Body did not explain how the phenomenon of price suppression should be identified, or clarify how the causal relationship between dumped or subsidized imports and price suppression/depression should be established. The lack of a clear standard for finding the effect of price suppression and price depression under Articles 3.2 and 15.2 has led to confusion and uncertainties.

\subsection{Main arguments advanced}

In its Redetermination, MOFCOM found that subject imports (i) suppressed domestic prices in 2008 and (ii) suppressed and depressed domestic prices in Q1 2009. With respect to price suppression, MOFCOM found that the domestic industry was unable to raise prices despite rising costs, and cited the following as the causes: (a) increases in the volume of subject imports, (b) the loss of market share of the domestic industry predominantly to subject imports, and (c) price competition between subject imports and domestic like products.

The controversy over MOFCOM's finding of price suppression centred on the question of whether a comparison between prices of subject imports and domestic like products is required. MOFCOM did not make such a price comparison in the Redetermination. The United States argued that MOFCOM could not have concluded that subject imports had the effect of price suppression without comparing the actual prices of subject imports and the domestic like products. ${ }^{10}$ According to the United States, MOFCOM failed to compare the prices of subject imports and domestic like products, despite evidence in the record indicating that there was a substantial divergence in the prices of subject imports and domestic like products. ${ }^{11}$ In response to the US argument, China contended that Articles 3.2 and 15.2 do not require investigating authorities to compare the prices of subject imports and domestic like products, citing the Appellate Body's statement that, in light of the text of Articles 3.2 and 15.2, price suppression or depression may stem from 'the prices and/or volume of such imports' ${ }^{12}$

As third parties in the dispute, Japan and the European Union expressed their respective opinions. Agreeing with the United States, Japan argued that an increase in the volume of subject imports or parallel pricing between subject imports and the domestic like products only establishes the potential for price suppression or depression, and not actual price suppression or depression by subject imports. ${ }^{13}$ The EU, on the other hand, was of the view that an increase in the volume of

9 Ibid., paras. 137,138 , and 141.

10 Panel Report, China-GOES 21.5, para. 7.29.

11 Ibid., para. 7.43 .

12 Ibid.

13 Ibid., para. 7.38 . 
subject imports and a decline in the domestic industry's market share, taken together with the existence of price competition between subject imports and the domestic like products, will generally indicate that subject imports suppress or depress domestic like products. However, the EU also added that, while in principle it may be possible to establish price competition between subject imports and the domestic like products without comparing the prices of subject imports and the domestic like products, it is unclear whether in practice it is possible to do so. ${ }^{14}$

\subsection{The Panel's ruling}

Unlike the parties, the Panel did not consider the issue in this case to be whether price comparisons are mandated for the finding of price suppression under Articles 3.2 and 15.2. According to the Panel, since Articles 3.2 and 15.2 do not prescribe any particular methodology for the consideration of the effect of price suppression or depression, 'investigating authorities retain some degree of discretion in adopting a methodology they deem fit'; but this discretion 'is qualified by the overarching obligation set out in Articles 3.1 and 15.1 that investing authorities shall base their determinations on an objective examination of positive evidence of, inter alia, the effect of subject imports on the market prices of domestic like products'. 15

Consequently, the Panel did not consider it necessary to determine whether price comparisons are required in finding price suppression under Articles 3.2 and 15.2 'as a general matter of law'. Instead, it would consider 'whether MOFCOM's failure to make price comparisons in this particular case, in light of the evidence and arguments before it, meant that it failed to make reasoned determinations regarding price effects on the basis of an objective examination of positive evidence'. ${ }^{16}$ The Panel answered the question in the affirmative, citing two reasons. First, the Panel faulted MOFCOM for failure to consider the impact of nonsubject imports (i.e., GOES imports not targeted in this particular AD/CVD investigation) on prices of domestic like products. ${ }^{17}$ Second, recalling that there was information before MOFCOM on the prices of subject imports, non-subject imports, and domestic like products, the Panel found that 'MOFCOM could not have reached a reasoned and adequate conclusion that the domestic industry's prices were suppressed by the volume of subject imports, having failed to consider the relative prices of subject imports and the domestic like product at all'. ${ }^{18}$ This second reason, however, appears to be circular: MOFCOM's failure to make 
price comparisons in this case is wrong because MOFCOM failed to make such price comparisons.

In sum, the Panel declined to decide whether, as a matter of law, price comparisons between subject imports and the domestic like products are required in identifying the effect of price suppression under Articles 3.2 and 15.2, but nonetheless concluded that MOFCOM's failure to make such price comparisons in this particular case is inconsistent with the Articles because MOFCOM's finding was not 'based on an objective examination of positive evidence' as required by Articles 3.1 and 15.1. In other words, as a matter of applying the law, the Panel held that price comparisons between subject imports and the domestic like products are required for finding the effect of price suppression in this particular case.

Unfortunately, the Panel's reasoning does not help clarify the criteria for finding the effect of price suppression. By design, Articles 3.1 and 15.1 set out the overarching obligation on injury determination in antidumping and countervailing investigations, and Articles 3.2 and 15.2 elaborate what such obligation entails with respect to the price effects of dumped or subsidized imports on domestic like products. Instead of clarifying what is required in identifying the effect of price suppression, the Panel relied on the general principle set out in Articles 3.1 and 15.2 to find non-compliance with Articles 3.2 and 15.2. The Panel's approach begs the question: what constitutes 'an objective examination of positive evidence' for the purpose of determining the effect of price suppression?

\subsection{Why a counterfactual analysis should be required}

We submit that for determining the effect of price suppression under Articles 3.2 and 15.2, a counterfactual analysis should be required as a matter of law. Our reasons are as follows.

First, the text of Articles 3.2 and 15.2 implies a requirement to consider a counterfactual situation. As already noted, Articles 3.2 and 15.2 provide that, with respect to price suppression, the investigating authorities 'shall consider' whether the effect of dumped or subsidized imports is to 'prevent price increases, which otherwise would have occurred, to a significance degree'. The subjunctive mood of the provision suggests that the investigating authorities should find out where the prices of domestic like products would have been without the presence of dumped or subsidized imports. Obviously, this level of domestic price cannot be observed in reality, but is a counterfactual situation.

Contextually, the concept of price suppression also exists in SCM Article 6.3(c), which has been interpreted by the Appellate Body to require a counterfactual analysis. SCM Article 6.3 details the meaning of 'serious prejudice', one of the adverse effects that may be caused by subsidies as identified by Article 5(c). Article 6.3(c) states that serious prejudice may arise where:

the effect of the subsidy is a significant price undercutting by the subsidized product as compared with the price of a like product of another Member in the 
same market or significant price suppression, price depression or lost sales in the same market. (italics added)

In United States-Upland Cotton (21.5-Brazil), the Appellate Body has interpreted the concepts of 'price suppression' and 'price depression' contained in Article 6.3 (c). The following statement of the Appellate Body is worth quoting in full: ${ }^{19}$

At a conceptual level, we see some differences between the concepts of 'price depression' and 'price suppression' as defined in the original proceedings. While price depression is a directly observable phenomenon, price suppression is not so. Falling prices can be observed; by contrast, price suppression concerns whether prices are less than they would otherwise have been in consequence of various factors, in this case, the subsidies. The identification of price suppression, therefore, presupposes a comparison of an observable factual situation (prices) with a counterfactual situation (what prices would have been) where one has to determine whether, in the absence of the subsidies (or some other controlling phenomenon), prices would have increased or would have increased more than they actually did. Price depression, by contrast, can be directly observed, in that falling prices are observable. The determination of whether such falling prices are the effect of the subsidies will require consideration of what prices would have been absent the subsidies. Thus, counterfactual analysis is an inescapable part of analysing the effect of a subsidy under Article 6.3(c) of the SCM Agreement.

The Appellate Body then stated that one way to undertake the counterfactual analysis is 'to use economic modelling or other quantitative techniques', because these techniques 'provide a framework to analyse the relationship between subsidies, other factors, and price movement'. ${ }^{20}$ According to the Appellate Body, 'the relative complexity of a model and its parameters is not a reason for a panel to remain agnostic about them' ${ }^{21}$

In EC and Certain Member States-Large Civil Aircraft, the Appellate Body confirmed again that the use of a counterfactual analysis provides an adjudicator with a useful analytical framework to isolate and properly identify the effects of the challenged subsidies. In that context, the Appellate Body further explained:22

In general terms, the counterfactual analysis entails comparing the actual market situation that is before the adjudicator with the market situation that would have existed in the absence of the challenged subsidies. This requires the adjudicator to undertake a modelling exercise as to what the market would look like in the absence of the subsidies. Such an exercise is a necessary part of the counterfactual

19 Appellate Body Report, United States - Subsidies on Upland Cotton, Recourse to Article 21.5 of the DSU by Brazil, WT/DS267/AB/RW, adopted 20 June 2008, para. 351 (italics added).

20 Ibid., para. 356.

21 Ibid., para. 357.

22 Appellate Body Report, European Communities and Certain Member States-Measures Affecting Trade in Large Civil Aircraft, WT/DS316/AB/R, adopted 1 June 2011, para. 1110. 
approach. As with other factual assessments, panels clearly have a margin of discretion in conducting the counterfactual analysis.

Thus, the Appellate Body has by now established a clear standard under SCM Article 6.3(c): In order to find if a subsidy has the effect of 'significant price suppression', the adjudicator must undertake a counterfactual analysis that involves a modelling exercise.

It should be noted that, in the original proceedings of China-GOES, the Appellate Body did refer to the concepts of price suppression and price depression in SCM Article 6.3(c), including a citation to its interpretation of the concepts in US-Upland Cotton (21.5-Brazil) quoted above. ${ }^{23}$ The Appellate Body made the references in the context of discussing the relationship between dumped or subsidized imports and domestic prices. By referring to its interpretation of the same concepts in SCM Article 6.3(c), the Appellate Body reinforced its view that Articles 3.2 and 15.2 require the investigating authorities to establish a causal link between subject imports and price suppression or depression. By focusing on the issue of relationship between subject imports and domestic prices, however, the Appellate Body did not discuss whether a counterfactual analysis should be required in finding the effect of price suppression or depression under Articles 3.2 and 15.2 .

In this regard, one might question whether it is appropriate to set the same standard for the determination of price suppression and price depression under Articles 3.2 and 15.2 as under SCM Article 6.3. Other commentators have suggested that the Appellate Body might hold the Panel determination under Article 6.3 to a higher standard, since the Panel operates as the initial trier of facts in the 'serious prejudice' determinations, whereas in the context of antidumping and countervailing investigations, the Appellate Body seemed satisfied to have panels engage in procedural rather than substantive review of national agency determinations (Sapir and Trachtman, 2008; Davey and Sapir, 2010).

In our opinion, requiring the national authority to undertake a counterfactual analysis under Articles 3.2 and 15.2 does not necessarily mean the review standard for the national agency determinations must be the same as that for the Panel determinations under SCM Article 6.3. What at issue here is not the review standard, but how the concept of price suppression should be interpreted. Does the concept of price suppression have an inherent economic logic, i.e., does it presuppose a comparison between a factual situation and a counterfactual situation? Does a counterfactual analysis necessarily entail a modelling exercise? If the answer to these questions is affirmative, then there should be no reason not to require the national authorities to undertake such counterfactual analysis under Articles 3.2 and 15.2. Put differently, whether the effect of price suppression requires a counterfactual analysis is a matter of interpreting the term of Article 3.2 and 15.2, not a matter 
of setting a review standard. So long as the national authority conducts the required analysis, the Panel and Appellate Body can review such analysis according to whatever standard of review that is deemed proper under those provisions.

As Prusa and Vermulst (2014:198) pointed out insightfully in their comment on the original proceedings of China-GOES, the Panel in the case did not address the critical question of what constitutes a proper price effects analysis under Articles 3.2 and 15.2. Consequently, it remains unclear what China, or for that matter any other Member, needs to do in future cases in order to produce a satisfactory price analysis. According to their observation, the problem with China's price effect analysis in the case was to a large extent due to its poor documentation of the basis for determining that subject imports had caused price depression and/or price suppression. In practice, "neither the US nor the EU rigorously assess the impact that alternative factors might have played in the evolving pricing dynamics', but their facility with public reporting largely obscures the fact. Having identified the lack of a real standard as the key issue in the price effects analysis, Prusa and Vermulst (2014: 259-261) also recommended the use of econometric techniques for the future.

\section{Economic analysis: methods to determine the causal link between subject imports and price effects}

The key issue in the $\mathrm{AD} / \mathrm{CVD}$ injury determination is causality. While the overall causal relationship between dumped or subsidized imports and injury to the domestic industry is examined under ADA Article 3.5 and SCM Article 15.5, the determination of price effects under Articles 3.2 and 15.2 forms part of 'the basis' for the overall causation analysis contemplated in Articles 3.5 and 15.5. ${ }^{24}$ With respect to the inquiries under Articles 3.2 and 15.2, the Appellate Body has required an investigating authority to consider whether subject imports have "explanatory force' for the occurrence of significant depression or suppression of domestic prices. ${ }^{25}$ In deciding whether such explanatory force exists, 'the authority is not required to conduct a fully fledged and exhausitve analysis of all known factors that may cause injury to the domestic industry, or to separate and distinguish the injury caused by such factors'. ${ }^{26}$ Nonetheless, 'where the authority is faced with elements other than subject imports that may explain the significant depression or suppression of domestic prices, it must consider relevant evidence pertaining to such elements for purposes of understanding whether subject imports indeed have a depressive or suppressive effect on domestic prices'. ${ }^{27}$

24 Appellate Body Report, China-GOES, para. 143.

25 Ibid., para. 136.

26 Ibid., para. 151 (italics original).

27 Ibid., para. 152. 
With the above causality standard in mind, in this section we will first explain why the suppressive or depressive effect of subject imports on domestic prices has not been shown in MOFCOM's Redetermination. We will then procced to explain why trends analysis, which has typically been accepted as a method for injury determination, is not sufficient as a causality test for price effects determination. We will then propose alternative methods that can provide a causality test much closer to the spirit of the law.

\subsection{MOFCOM's causality analysis}

In a nutshell, the reasoning put forward by MOFCOM for causality of price effects goes as follows. Imports from subject countries (USA and Russia ${ }^{28}$ ) rose by $60 \%$ in 2008. This resulted in an increase of $5.56 \%$ in the market share of subject countries, which then suppressed the prices of China's domestic producers. While the factual evidence presented by MOFCOM (see Table 1) indicates an actual increase in prices for the domestic Chinese GOES of $14.53 \%$ in 2008 , this increased level in prices was allegedly much below what should have been the level of Chinese GOES prices in the absence of subject imports, hence Chinese domestic GOES suffered price suppression. ${ }^{29}$ MOFCOM reasoned that in 2008, unit production costs of domestic producers rose by $63 \%$, which should have resulted in a much higher increase in the prices of domestic GOES if domestic producers could have passed through the increase in costs to market prices as in times of normal competition. MOFCOM determined that the inability for domestic producers to raise the prices of GOES was due to the strong rise in the volume of subject imports.

The Panel did not find this sufficient to conclude that subject imports resulted in price suppression of domestic GOES. One reason given by the Panel that questioned the linkage between subject imports and price suppression was that nonsubject imports were almost double the size of subject imports (Table 1, col. 4) and that the prices of non-subject imports did not differ much from subject imports (Table 1, col. 8). Hence the Panel questioned how MOFCOM could come to the conclusion that the inability to raise domestic prices was entirely driven by subject imports. Another concern the Panel raised was that in 2008 a new Chinese GOES producer, Baosteel, had entered the market. This new entry may have resulted in overcapacity and could subsequently also have lowered Chinese GOES prices, thus questioning whether subject imports were the main cause of domestic price suppression. Moreover, as noted in Section 2, the Panel faulted MOFCOM for not making a price comparison between subject imports

28 China's antidumping measures were brought against GOES imports from the United States and Russia. Russia did not take part in the WTO case.

29 MOFCOM also found price depression as well as price suppression in 2009 Q1, during which domestic GOES prices actually declined compared to 2008 Q1. 
Table 1. GOES facts

\begin{tabular}{|c|c|c|c|c|c|c|c|c|c|}
\hline Year & $\begin{array}{l}\text { Subject } \\
\text { Imports } \\
\text { (tons) } \\
(1)\end{array}$ & $\begin{array}{l}\text { Subject Imports } \\
\text { \% Change in } \\
\text { Volume } \\
\text { (2) }\end{array}$ & $\begin{array}{c}\text { Subject } \\
\text { Imports } \\
\text { Market Share } \\
\text { (3) }\end{array}$ & $\begin{array}{l}\text { Non-Subject } \\
\text { Imports } \\
\text { (tons) } \\
\text { (4) }\end{array}$ & $\begin{array}{c}\text { Domestic } \\
\text { Producer Market } \\
\text { Share \% Change } \\
\text { (5) }\end{array}$ & $\begin{array}{l}\text { Price Subject } \\
\text { Imports } \\
\text { (RMB/ton) } \\
(6)\end{array}$ & $\begin{array}{l}\text { Price Subject } \\
\text { Imports \% } \\
\text { Change } \\
\text { (7) }\end{array}$ & $\begin{array}{c}\text { Price Non- } \\
\text { Subject Imports } \\
\text { (RMB/ton) } \\
(8)\end{array}$ & $\begin{array}{l}\text { Price Domestic } \\
\text { Products \% } \\
\text { Change } \\
\text { (9) }\end{array}$ \\
\hline 2006 & 83838 & & & 169845 & & 25913 & & 25468 & \\
\hline 2007 & 84600 & $+0.91 \%$ & $-3.35 \%$ & 183348 & $+7.9 \%$ & 26683 & $-2.9 \%$ & 28700 & $+6.6 \%$ \\
\hline 2008 & 135900 & $+60 \%$ & $+5.56 \%$ & 213516 & $-5.65 \%$ & 31371 & $+17.6 \%$ & 30999 & $+14.43 \%$ \\
\hline
\end{tabular}

Source: MOFCOM Redetermination (2013) 
and domestic like products, which the Panel deemed necessary in this particular case to provide conclusive evidence on price supression.

\subsection{Alternative methods for establishing causality}

The question we aim to address here is not whether MOFCOM was right or wrong in claiming price suppression - we simply do not have conclusive evidence to answer that question. Instead, we ask ourselves what MOFCOM could have done differently to make a more convincing case for domestic price suppression. What would have been needed to convince the Panel that subject imports have 'explanatory force' for the suppression of domestic prices?

As already pointed out, establishing price suppression requires the construction of a counterfactual. A counterfactual analysis demonstrates what Chinese domestic GOES prices would have been in the absence of subject imports. But how to engage in such a counterfactual analysis? As noted above, since WTO law does not prescribe any particular methodology in determining price supression, WTO members retain a certain degree of discretion in choosing their own methodology. Although such discretion 'is not without limits', 30 the Panel did not specify these limits. Consequently, it is up to WTO adjudicators to decide what these limits should be in each particular case.

Below we present a number of techniques that have been used by other WTO members to make a convincing case of the causal link between subject imports and domestic prices. For each method, we assess its usefulness in determining causality.

\subsubsection{Trends analysis}

In several antidumping cases initiated by the EU and the US, the investigating authorities used 'trends analysis' as a way to provide evidence of linkage between subject imports and evolution in domestic prices, as required by ADA Articles 3.2 and 3.5. For example, Prusa and Sharp (2001) report that for the United States, the traditional injury analysis conducted by the International Trade Commission (USITC) has long consisted of 'trends analysis'. While this type of analysis varies from case to case, its overall structure typically consists of a review of time series data pertaining to (1) the imports under investigation; (2) the prices for sales of the relevant imports and their domestic counterparts; and (3) lost sales or revenue on domestic transactions. More specifically, in a 'typical' antidumping case, the investigating authority considers in parallel, the evolution of imports and the evolution of domestic variables. Often, these parallel trends are illustrated graphically during the course of the investigation period,

30 Panel Report, China-GOES 21.5, para. 7.41. 
which typically involves time series data up to three years prior to the initiation of an $\mathrm{AD}$ case during which suspicions of dumping of subject imports arise.

Consider the following hypothetical example illustrated in Figure 1(a) where it is clear that a rising trend in subject imports during the investigation period (from $\mathrm{t}-3$ onwards) coincides with a falling trend in domestic market share of a particular product. Moreover, note from the example that during the investigation period, a clear reversal of trends occurred. Before $t-3$, subject imports were stable and domestic market shares were on a postive trend, whereas during the investigation period after $\mathrm{t}-3$, subject imports rose strongly, while the domestic sales' trend reversed and started falling.

Additionally, suppose that in the same example the evolution of subject import prices were given as in Figure 1(b), where a fall in subject import prices would be followed by a parallel trend in domestic prices. Again, visual inspection of Figure 1 (b) clearly suggests that from t-3 onwards, foreign subject import prices started falling strongly which coincided with a reversed trend for domestic prices that also started falling.

To claim causality between subject imports and trends in domestic prices, the investigating authority in this hypothetical example would then also need to show that non-subject import trends evolve differently than subject imports. Again consider Figure 1(a), where non-subject imports are also shown, but where it is clear that their time trend did not change drastically during the investigation period. And when considering Figure 1(b), we also note that the trend in prices of non-subject imports evolved differently than for subject imports, i.e. remained relatively stable even during the investigation period.

Based on the hypothetical example presented in Figures 1(a) and 1(b), an investigating authority could make a convincing case that the downward trends in domestic sales and domestic prices is caused by subject imports which becomes clear through visual inspection of parallel trends. Note that it is immaterial whether domestic prices lie above or below the foreign prices, but what is important is the parallel movement in subject import prices and domestic prices. In other words, when trend reversals occur for both import prices and domestic prices around the same time during the dumping period, there is a strong suspicion of injury.

Now how does trend analysis provide for a counterfactual? A counterfactual can be constructed from the pre-investigation period trends of foreign and domestic variables. In other words, counterfactual values are given if the trends would have continued as they did before the dumping of subject imports. Such trends analysis provides a simple way to construct counterfactual prices or even counterfactual imports.

To illustrate what we mean by that, consider the dashed lines in Figure 1(a) and 1(b). The dashed lines show a continuation of the trend for domestic sales along the lines of pre-investigation period trends. And similarly for domestic prices, the dashed lines show how domestic prices would have evolved in the absence of a 
Figure 1. (a) Quantity evolution. (b) Price evolution

(a)

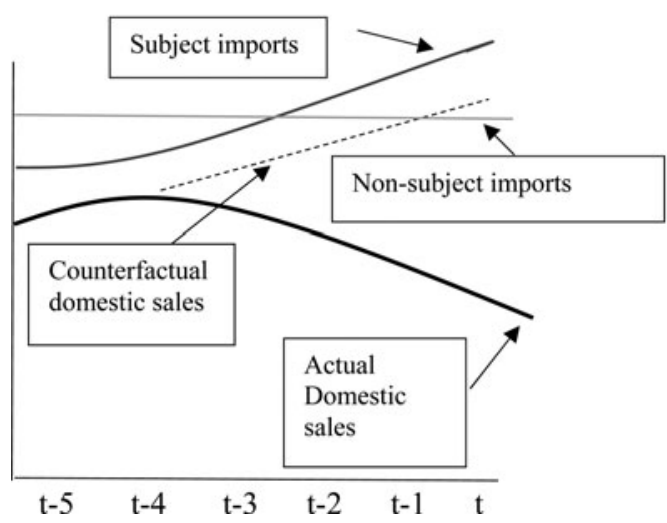

(b)

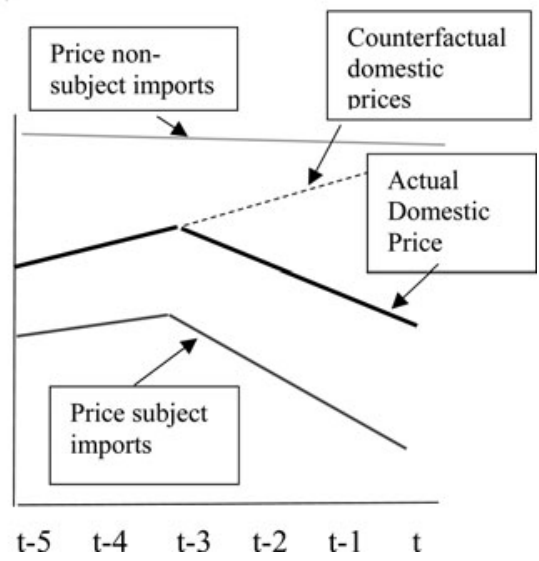

Source: Panel Report, China-GOES 21.5, para. 7.150.

rise of subject imports and what domestic prices would have been in any particular year after the rise in subject imports. Hence, based on trends analysis one can construct counterfactual market shares and prices based on time series trends in the data observed prior to the investigation period. If, in any particular year, the actually observed domestic prices lie substantially below what the domestic prices would have been according to pre-investigation period trends, as shown on the dashed line as is the case in Figure 1(b), the investigating authority can convincingly claim price suppression/depression. Domestic price suppression/depression then refers to the lack of increase or decrease in domestic prices from $\mathrm{t}-3$ onwards.

MOFCOM did not present a 'typical' trends analysis as the one illustrated in Figures 1(a) and 1(b). This may have been the reason that the evidence presented by MOFCOM was not considered convincing by the US and by the Panel. The question then is what the evidence would have looked like in the GOES case if MOFCOM had turned to a trends analysis. The investigation period, i.e. the period during which the US was accused of dumping, is very short and only involved 2008 and the first quarter of 2009, which makes it difficult to observe particular trends. Based on the data presented by MOFCOM and shown in Table 2 below, we graph the pattern of subject and non-subject imports in Figure 2(a) and 2(b).

A visual inspection of Figure 2(a) does not suggest a different trend in subject imports (in black) versus non-subject imports (in gray) of GOES, which is what would be required for a linkage between subject imports and the evolution of domestic prices. Similarly Figure 2(b) does not show a markedly different trend in import pricing between subject (black) and non-subject imports (gray), except for the first quarter of 2009 in which subject import prices lie below that of 
Table 2. Volumes and prices of subject and non-subject imports

\begin{tabular}{lcccc}
\hline \hline & $\begin{array}{c}\text { Subject Imports } \\
\text { Volume (tons) }\end{array}$ & $\begin{array}{c}\text { Subject Imports } \\
\text { Price (RMB/ton) }\end{array}$ & $\begin{array}{c}\text { Non-Subject Imports } \\
\text { Volume (tons) }\end{array}$ & $\begin{array}{c}\text { Non-Subject Imports } \\
\text { Price (RMB/ton) }\end{array}$ \\
\hline $\mathbf{2 0 0 6}$ & 83,837 & 25,913 & 169,846 & 25,468 \\
$\mathbf{2 0 0 7}$ & 84,600 & 26,684 & 183,349 & 28,701 \\
$\mathbf{2 0 0 8}$ & 135,900 & 31,372 & 213,517 & 30,999 \\
Q1 2009 & 19,400 & 26,673 & 54,206 & 32,359 \\
\hline \hline
\end{tabular}

Source: Panel Report, China - GOES 21.5, para 7.150.

non-subject imports, but the 2009 prices are still higher than the 2006 prices, so one cannot really speak of a trend reversal.

More importantly, what is lacking in Figures 2(a) and 2(b) is an evolution of the domestic sales in tons and levels in domestic prices (RMB/ton) of GOES, respectively. Hence, the trends in subject and non-subject variables cannot be compared with the corresponding Chinese values as this information was lacking and not revealed by MOFCOM. The only numbers made available by MOFCOM were a relative evolution (in \%) of domestic market shares and of changes in domestic prices, as shown in Table 1 in columns (5) and (9), respectively. MOFCOM argued that it did not reveal prices because the Chinese petitioners requested confidentiality. To make a convincing case, however, MOFCOM could have shown the evolution of domestic sales in tons and the domestic prices to the Panel on a confidential basis. ${ }^{31}$ In short, the evidence presented by MOFCOM does not allow for a simple trends analysis to be made in this case.

Trends analysis, however, has its limits. Because trends analysis heavily relies on visual inspection of trends, it is considered as 'more art than science' (Prusa and Sharp, 2001). While these trends are clearcut in our hypothetical example, such is not always the case in reality (Ahn and Zanardi, 2016).

More importantly, trends analysis is not sufficent to demonstrate causality between subject imports and price effects. That is because trends analysis does not go beyond documenting correlations in the data, and a correlation does not necessarily prove causality. Put differently, documenting that the two variables subject import prices and domestic prices - move in the same direction is not conclusive evidence of the subject import prices causing a drop of domestic prices. The reason is that correlations do not exclude the possibility that third variables, other than subject import prices, also have an effect on domestic prices, e.g.,

31 Under DSU Article 13, a Member has the obligation to 'respond promptly and fully to any request by a panel for such information as the panel considers necessary and appropriate'; and the panel may not reveal any confidential information without 'formal authorization' from the Member providing the information. 
Figure 2(a). Trends of subject and non-subject GOES imports (tons) (b) Trends in prices of subject and non-subject imports in GOES (RMB/ton)

(a)

\section{$2,50,000$}

$2,00,000$

$1,50,000$

$1,00,000$

50,000

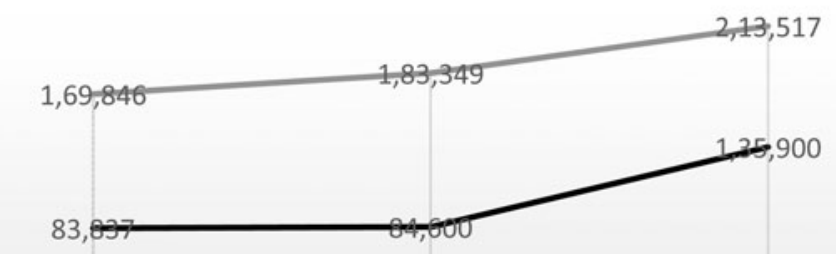

0

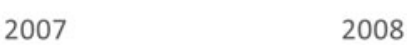

- subject imports — non-subject imports

(b)

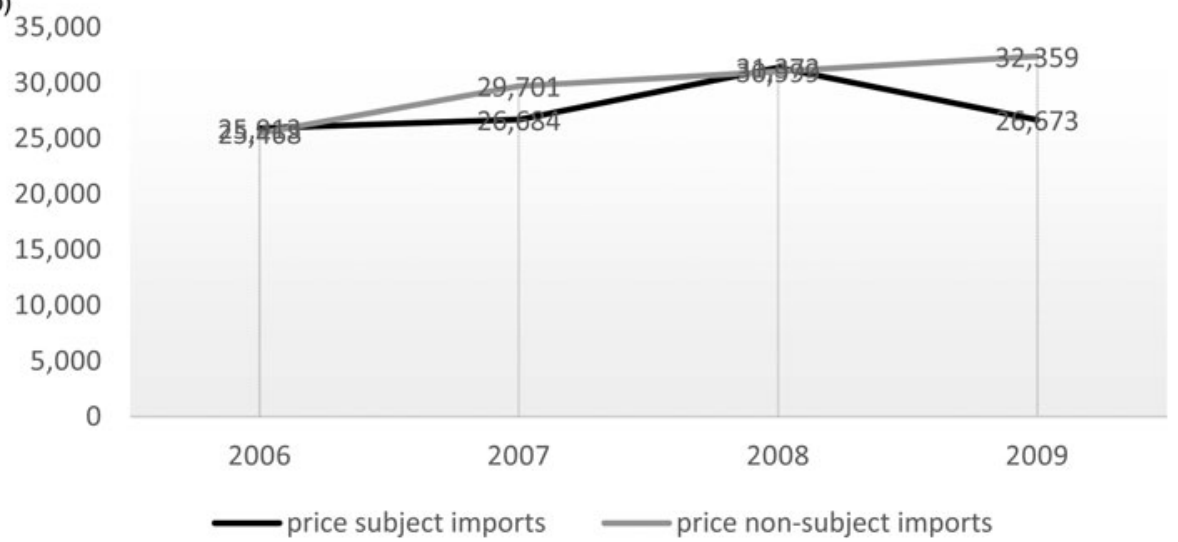

Source: Data in Table 2.

overproduction by the domestic industry, or non-subject import prices, or macroeconomic variables (financial crisis), which may also be at play to a small or large extent. Trends analysis is not equipped to disentangle the importance of each of these factors, since it does not attribute weights to the different factors that may explain domestic prices. Thus, trends analysis is not suitable to serve as the standard methodology for identifying the effect of price suppression/depression under ADA Article 3.2 and SCM Article 15.2.

MOFCOM, therefore, would best have chosen alternative methods to claim the effect of price suppression/depression to begin with. In fact, in the late 1980s, the USITC in several of its cases already started questioning the validity of trends analysis due to its subjective interpretation. Below we describe two alternative methods 
that economists consider to correspond to empirical economic modeling and constitute an objective way of engaging in injury investigations in general.

\subsubsection{Regression analysis}

The subdiscipline in economics that offers a toolbox of statistical techniques and regression analysis to establish causality between variables is called econometrics. Econometrics allows economists to determine whether there is an economically significant impact of one variable on another. This is typically done by first collecting time series data on the variables and then applying regression analysis on these data.

Hence, to an economist, the causality test is a matter of regression analysis and econometrics which uses time series data (indicated by $t$ ). A relatively simple approach would be to estimate a regression equation as in (1) in which the evolution of Chinese domestic prices of GOES would be the dependent variable $(y)$ on the left side of the equation which varies in every year $t$ and for every firm $i$. All the explanatory variables that potentially can have an impact on domestic prices $\left(y_{i t}\right)$ would be on the right-hand side of the regression equation and would include variables such as US import prices $\left(x_{1 t}\right)$, Russian import prices $\left(x_{2 t}\right)$ but would now also include non-subject import prices $\left(x_{3 t}\right)$, Chinese production $\left(x_{4 t}\right)$, and Chinese demand for steel $\left(x_{5 t}\right)$. One cannot exclude that other variables may also affect domestic prices, other than $x_{1 t}$ to $x_{5 t}$. To address that, equation (1) also includes year effects $\left(\vartheta_{t}\right)$ and firm-level fixed effects $\left(\theta_{i}\right)$ and a rest category $(\varepsilon)$ :

$$
y_{i t}=\alpha+\beta \cdot x_{1 t}+\gamma \cdot x_{2 t}+\delta \cdot x_{3 t}+\mu \cdot x_{4 t}+\rho \cdot x_{5 t}+\theta_{i}+\vartheta_{t}+\varepsilon_{i t}
$$

Any statistical software package designed for regression analysis allows one to estimate a regression equation as in equation (1) above. It will generate estimates for the relevant regression coefficients $(\beta, \gamma, \delta, \mu, \rho)$ whenever sufficient data observations are available. ${ }^{32}$ These regression coefficients then provide a useful indication on how important each of the right-hand side variables $\left(x_{1}, x_{2}, x_{3}, x_{4}, x_{5}\right)^{33}$ are for explaining Chinese domestic prices of GOES $\left(y_{i t}\right)$, the left-hand side variable of regression equation (1).

32 Regression coefficient $\alpha$, can be considered as a constant and a control variable to estimate the other regression coefficients correctly.

33 The last three variables are important in the estimation of equation (1), but require a more technical explanation that is not necessary to understand the main message. The variable $\vartheta_{t}$ is typically referred to as 'time dummies' and controls for business cycle effects that may affect domestic prices $\left(y_{i t}\right)$. The variable $\theta_{i}$ accounts for firm-level variables that may be difficult to observe or collect information on such as the cost of inputs, the wages paid, the profit margin charged, etc. and are referred to as firm-fixed effects which means they enter the regression as firm dummies which are assumed constant over the years and finally $\varepsilon_{i t}$ is a 'rest category' and represents the data variation of $y_{i t}$, that remains unexplained by the right-hand side determinants of domestic prices included in equation (1). This rest category does not generate a regression coefficient. These last three variables are well understood by any econometrician but a further explanation on them would take us too far here. Therefore, we refer to Wooldridge (2009), a standard econometrics textbook, for the interested reader. 
The regression coefficients of explanatory variables can then be tested for their statistically significant impact on the left-hand side variable. Put differently, regression analysis allows the econometrician to determine whether a variable such as 'subject import prices' $\left(x_{1 t}\right)$ has a significant effect on 'Chinese domestic prices' $\left(y_{i t}\right)$, and compare the significance relative to that of other right-hand side variables in the regression. This way it is relatively straightforward to determine whether 'non-subject import prices' $(\delta)$ has more of an effect on the domestic market share of steel in China, as the US claimed, than the 'subject import prices' $(\beta)$. A negative and significant value for the $\beta$-coefficient resulting from the regression analysis can then be interpreted as evidence in line with the allegation that the 'subject import prices' had a negative impact on domestic prices and domestic prices would have been higher in the absence of dumped or subsidized imports.

A significant difficulty with such a regression analysis is that most right-hand side explanatory variables are 'endogenous', which would result in biased regression coefficients that may not be trusted. For example, there can be a problem of 'reverse causality' between Chinese domestic prices and Chinese production: Chinese production is likely to affect domestic prices in China, but simultaneously, the prices at which GOES can be sold in China will determine the number of producers offering it to the market, and hence will determine total domestic production, which is the basic law of supply and demand in economics. In the case of this potential two-way causality, one cannot correctly estimate the regression coefficient on the importance of 'Chinese production' as a determinant on Chinese domestic steel prices. The theory of econometrics however provides several possible ways to deal with endogenous variables in order to get unbiased estimates for regression coefficients. One common solution is to replace each endogenous variable with a good instrument (alternative variable) that does not suffer from the two-way causality but is highly correlated with the endogenous variable. ${ }^{34}$ For example, in the case of 'Chinese production' $\left(x_{4 t}\right)$, one can consider taking as an alternative variable Chinese GOES exports abroad. It is clear that Chinese exports are likely to be highly correlated with Chinese production, thus making it a good potential candidate as an instrumental variable. In addition, Chinese exports will not suffer from two-way causality as the demand for Chinese GOES exports is unlikely to be affected by the domestic prices of Chinese GOES, potentially making it a good instrument to deal with the endogeneity of the variable 'Chinese production'.

To estimate all the regression coefficients in equation (1) correctly, therefore, one would have to find good 'instruments' for all the endogenous variables. While such an econometric exercise is by no means simple or straightforward, it is nevertheless

34 The theory of econometrics has shown that a good 'instrument' (alternative variable) has to be highly correlated with the endogenous variable but should not be affected by two-way causality. For additional explanation on these econometric issues, we refer the reader to standard econometrics textbooks such as Wooldridge (2009). 
feasible thanks to the techniques offered by the theory of econometrics. A clear indication of the merits of econometrics and the benefits it can render is that other fields of the law have long been using it. For instance, in the field of competition policy and merger analysis, economic and econometric modeling plays an important role in decision-making (Budzinski and Ruhmer, 2010). Thus, in our opinion, the application of econometric modelling can also make AD/CVD practice more objective, transparent, and less idiosyncratic.

In our view, MOFCOM could have turned to regression analysis without violating the confidentiality restriction requested by the Chinese petitioner. This could have been done in one of two ways. First, MOFCOM could have defined domestic prices, the dependent variable $y$ in the regression equation (1), as an index variable, where the actual values of Chinese domestic prices could have been normalized ${ }^{35}$ such that confidentiality would not have been breached. Second, it could have estimated regression equation (1) entirely in 'first differences' or in 'growth rates'. ${ }^{36}$ Econometric theory can show that estimating equation (1) in first differences should yield the same estimated regression coefficients $(\beta, \gamma, \delta, \mu, \rho)$ but with the additional advantage that it accounts for all omitted variables that are not time varying, ${ }^{37}$ such as the constant of the regression equation, given by $\alpha$ and all other variables that may affect domestic prices but that do not vary over time. ${ }^{38}$

However, the difficulty that MOFCOM would have faced in this particular case is that there were only two Chinese petitioners, which largely limited the number of data points available. The only data variation in regression equation (1) would come from the variation in domestic prices over time, which may not have been sufficient to get reliable regression coefficients. ${ }^{39}$ Therefore, while regression analysis in general can be regarded as much better equipped to address the causality issue, it requires a sufficient number of observations, ${ }^{40}$ which in this particular GOES case may not have been the case.

35 A normalization is often used in econometric variables. This implies that the absolute value of a variable in a particular year is set equal for example to ' 100 ' and the absolute values of the variable in subsequent years is expressed as an increase or decrease from ' 100 '. In such a way, the normalized variable correctly reflects the growth rate over time of the absolute values of the variable in question without revealing the actual values.

36 Thus, instead of $y$, we would define the left-hand side variable as $\frac{y_{t+1}-y_{t}}{y_{t}}$, which is a growth rate and similarly for all right-hand side variables. For more details, see Wooldridge (2009).

37 To see this, note that a constant does not vary over time so its growth rate turns 0 and it drops out of the regression in equation (1). For more details, see Wooldridge (2009).

38 The firm-fixed effects, such as $\theta_{i}$, would drop out of the equation when estimating equation (1) in first differences, which is helpful to estimate regression coefficients correctly.

$39 \mathrm{~A}$ rule of thumb in econometrics is that the larger the number of data points, the more reliable the estimated coefficients are. When there are very few data points, the statistical software may not generate any regression coefficients, hence estimation in equation (1) cannot be made.

$40 \mathrm{~A}$ minimum of 100 observations is typically regarded as the lower bound to perform regression analysis. 


\subsubsection{Structural modeling}

A more sophisticated econometrics approach would be the estimation of a structural model, in which the GOES steel market in China would be modelled with a demand equation and a supply equation. The structural econometric estimation would be directed at simultaneously estimating the parameters of the model, such as the elasticity of demand and the elasticity of supply in the domestic steel market. To correctly estimate the demand elasticity in the GOES market, however, one would need information on the cost of Chinese GOES production and/or other shifters that may affect the position of the domestic GOES supply curve. The advantage of a structural model is that upon identification of the demand and supply parameters, this then allows for counterfactual policy simulations and the evaluation of other policy experiments in the Chinese GOES industry. ${ }^{41}$ A fine example of such a structural approach is described by Prusa and Sharp who explain the methodology that was used by the USITC for the first time in 2000 on cold rolled steel (Prusa and Sharp, 2001: 63-78).

The estimation of such a structural model in principle has a similar objective as a simple regression analysis, that is, it can account for various factors that may influence the prices of domestically produced GOES. Therefore, a structural model would also allow MOFCOM to determine the extent to which a decline or the lack of increase in domestic market prices of GOES was actually attributable to subject imports.

In this particular case, MOFCOM may not have had a sufficient number of data points to estimate such a structural model. However, we consider this to be the exception rather than the rule. In most AD/CVD cases, there are more observations available on domestic petitioners, allowing for a sufficient number of data points to engage in structural modeling.

\section{Policy implications}

\subsection{Tightening WTO disciplines on antidumping and countervailing measures}

The methodology we proposed would have the effect of tightening WTO disciplines on injury determination in AD/CVD investigations, since it would narrow the scope of discretion currently enjoyed by the national authority in choosing methodologies to determine the price effects of subject imports under ADA Article 3.2 and SCM Article 15.2. But is such a discipline-tightening effect intended by the ADA and SCM Agreement?

In the original proceedings of China-GOES, China had submitted that the object and purpose of Articles 3.2 and 15.2 is to leave the authorities with discretion on

41 A further explanation of structural models would take us too far, but see Prusa and Sharp (2001) for further explanation on such an approach. 
the issue of price effects. The Appellate Body disagreed. According to the Appellate Body,

Articles 3 and 15 are intended to delineate the framework and relevant disciplines for the authority's analysis in reaching a final determination on the injury caused by subject imports, and to ensure that the analysis and the conclusion drawn therefrom is robust. Thus ... the requirement to consider whether subject imports have explanatory force for significant price depression or suppression occurring in the domestic market, pursuant to Articles 3.2 and 15.2, is not within the 'discretion' of the investing authority. ${ }^{42}$

If the Appellate Body is correct, then the discipline on conducting the price effect analysis under Articles 3.2 and 15 must be tightened. That is so because the scope of discretion currently enjoyed by the investing authorities in choosing methodologies for determining price effects cannot ensure that the price effect analysis and the conclusion drawn therefrom is 'robust'. The approach we proposed, in contrast, is capable of meeting the standard articulated by the Appellate Body.

\subsection{Feasibility of econometric modeling}

Econometrics is the application of mathematics and statistical methods in economics, which is of general utility in testing economic hypotheses and in helping distinguish between alternative explanations. It is true that econometricians can develop alternative solutions to test the same hypothesis. But if, no matter which econometric method is used, 'subject imports' always show up with a significant and negative coefficient in a regression analysis or structural modeling that aims to explain the evolution of domestic prices, one can truly speak of a 'robust' result which is unlikely to be questioned. ${ }^{43}$

We note that, in trade law and in AD/CVD law in particular, the use of econometrics by investigating authorities and by WTO panels remains relatively rare. This is in stark contrast with other fields of law. For example, in the field of competition law and policy, which is closely related to the field of industrial economics, the use of econometric modeling is more prevalent and econometrics has been widely accepted as a useful tool to support decision-making. If such is the case in related fields of law, it is hard to see why the same cannot, or should not, be done in $\mathrm{AD} / \mathrm{CVD}$ law, given what econometrics can potentially offer to decisionmaking in trade law and policy.

42 Appellate Body Report, China-GOES, para. 153.

43 Typically, the use of one econometric approach would not be regarded as sufficient evidence for new research results to be published in academic journals. Instead, authors would be required to show through the plethora of econometric methods that their results are 'robust'. 


\subsection{Defense against criticism of 'judicial activism'}

When there is no clear standard on how the effect of price suppression/depression should be determined, it is ultimately within the discretion of WTO adjudicators to decide whether a particular determination by the national authority is consistent with Articles 3.2 and 15.2. In exercising this discretion, however, the adjudicators are susceptible to criticisms that their decision is biased or that their decision amounts to 'adding to or diminishing the rights and obligations' provided in the ADA and SCM Agreement, in violation of DSU Article 3.2. By adopting the methodology that is grounded in econometric modeling, the adjudicators will forgo most of their (unwanted) discretion in deciding what is inherently a matter of economic evaluation rather than legal reasoning. By turning to expert opinions, therefore, WTO judges will be able to insulate themselves from potential accusation of 'judicial activism' in the interpretation and application of Articles 3.2 and 15.2. Needless to say, this can only help enhance the legitimacy of the WTO dispute settlement system.

\section{Conclusions}

What this case highlights is the lack of a clear standard for identifying the effect of price suppression and price depression under ADA Article 3.2 and SCM Article 15.2 that has led to much confusion and uncertainties in antidumping and countervailing investigations. Currently, the national authorities may choose a methodology they see fit in finding such price effects, subject only to the general obligation in Articles 3.1 and 15.2 that their findings shall be based on 'an objective examination of positive evidence'. What constitutes 'an objective examination of positive evidence' in the finding of price suppression/depression, however, remains undefined and subject to the interpretation of WTO adjudicators in each given case.

This state of affairs is in sharp contrast with WTO jurisprudence on 'price suppression' and 'price depression' under SCM Article 6.3(c), which lists such price phenomena as the types of 'serious prejudice' that may be caused by subsidies. In US-Upland Cotton and cases thereafter, the Appellate Body has made it clear that, in order to find price suppression and price depression caused by subsidies, the adjudicator must undertake a counterfactual analysis that involves modeling exercises.

In this comment, we have provided a legal analysis explaining why the same requirement established under SCM Article 6.3(c) should apply to the identification of price suppression and price depression under ADA Article 3.2 and SCM Article 15.2. We have then offered an economic analysis detailing how different econometric modeling exercises can help determine whether there is a causal link between subject imports and domestic prices, which is the key requirement in finding the effect of price suppression/depression under Articles 3.2 and 15.2. In addition, 
we have considered certain policy implications of our proposal. We believe the adoption by the national investigating authority of the same methodology as required by the Appellate Body under Article 6.3 is feasible in practice, considering that econometric modeling has already been widely accepted in competition laws and other fields of law under national legal regimes. Although there are limits on what economic modeling can offer in decision-making, and although modeling exercises are also susceptible to manipulation, there should be no doubt that a requirement to use the methodology as articulated by the Appellate Body under Article 6.3 will bring greater certainty and more transparency to the injury determination in antidumping and countervailing investigations. For this reason, the adoption of a clear and more objective standard for finding price suppression/ depression under ADA Article 3.2 and 15.2 should be in the long-term interest of all AD/CVD users, as well as the interest of the institution of WTO dispute settlement.

\section{References}

Ahn, D. and M. Zanardi (2016), 'China-HP-SSST: Last Part of Growing Pains', World Trade Review (forthcoming).

Budzinski, O. and I. Ruhmer (2010), 'Merger Simulations in Competition Policy: A Survey', Journal of Competition Law and Economics, 6(2): 277-319.

Davey, W. and A. Sapir (2010), 'United States: Subsidies on Upland Cotton Recourse to Article 2.15 by Brazil', World Trade Review, 9(1): 181-199.

Prusa, T. and D. Sharp (2001), 'Simultaneous Equations in Antidumping Investigations', Journal of Forensic Economics, 14(1): 63-78.

Prusa, T. and E. Vermulst (2014), 'China - Countervailing and Antidumping Duties on Grain Oriented Flat-rolled Electrical Steel from the United States: Exporting US AD/CVD Methodologies through WTO Dispute Settlement', World Trade Review, 13(2), 229-266.

Sapir, A. and J. Trachtman (2008), 'Subsidization, Price Suppression and Expertise: Causation and Precision in Upland Cotton', World Trade Review, 7(1): 183-208.

Wooldridge, A. (2009), Introductory Econometrics: A Modern Approach, South Western Cengage Learning. 